\section{Visceral leishmaniasis control actions: epidemiological indicators for its effectiveness evaluation in a Brazilian urban area}

\author{
Ações de controle da leishmaniose visceral: \\ indicadores epidemiológicos da avaliação de \\ efetividade em uma área urbana brasileira
}

\begin{abstract}
Acciones de control de la leishmaniosis visceral: indicadores epidemiológicos de la evaluación de efectividad en un área urbana brasileña
\end{abstract}

Maria Helena Franco Morais 1

Paulo Chagastelles Sabroza 2

José Eduardo Pessanha †

Andrea Sobral 2

doi: 10.1590/0102-311X00060219

\begin{abstract}
This research applies indicators concerning control of the visceral leishmaniasis canine reservoir in the city of Belo Horizonte, Minas Gerais State, Brazil. Data were obtained from the Zoonoses Control Information System (SCZOO) and the Brazilian Information System on Diseases of Notification (SINAN) database. First we analyzed (i) existing associations between canine epidemiological indicators, where the dependent variable was the canine seroprevalence A (2007 to 2013), and the independent variables were, as follows: canine seroprevalence $B$ (2006 to 2012); percentage of positive dogs by ELISA test reagents that were not euthanized; the relationship between the human and canine population; canine population testing coverage by census surveys; and the years of study (2006 to 2013); (ii) then, we examined the association between human visceral leishmaniasis (HVL) cases between 2007 to 2013 and the mentioned variables related to dogs and years. Statistical analysis was done by a generalized linear model (GLM). One unit increases in canine seroprevalence B and canine seroprevalence A were associated to $13 \%$ and $12 \%$ increases in HVL rates, respectively. The increase in one human/dog ratio unit was associated with a $13 \%$ decrease in HVL rates. Canine seroprevalence, human/dog ratio and non-euthanasia of ELISA-reactive dogs in the environment were adequate indicators for analyzing the canine enzootic transmission and the occurrence of HVL cases.
\end{abstract}

Visceral Leishmaniasis; Indicators of Health Services; Epidemiologic Surveillances

\author{
Correspondence \\ A. Sobral \\ Departamento de Endemias Samuel Pessoa, Escola Nacional de \\ Saúde Pública Sergio Arouca, Fundação Oswaldo Cruz. \\ Rua Leopoldo Bulhões 1480, Rio de Janeiro, RJ 21041-210, \\ Brasil. \\ andrea.almeida@ensp.fiocruz.br \\ 1 Gerência de Controle de Zoonoses, Prefeitura de \\ Belo Horizonte, Belo Horizonte, Brasil. \\ 2 Escola Nacional de Saúde Pública Sergio Arouca, \\ Fundação Oswaldo Cruz, Rio de Janeiro, Brasil. \\ † Deceased.
}




\section{Introduction}

Human visceral leishmaniasis (HVL) is a globally significant neglected disease ${ }^{1}$. In the last 30 years, visceral leishmaniasis (VL) has become a major challenge for surveillance and disease control programs in Brazil. Unlike other endemic diseases, such as Chagas disease, schistosomiasis, lymphatic filariasis and even malaria, programmatic actions did not result in VL control in Brazil. Several epidemics have struck urban areas and significant dissemination of this important health problem is noted 2 . This led to questioning regarding the scientific paradigm related to the transmission of this disease and the theoretical fundamentals of control actions. Brazil accounts for over 95\% of the HVL notifications in the Americas 3 , and the disease burden, characterized by missed years of life adjusted for death and disability, has increased $86 \%$ in the last 16 years 2 .

In Brazil, the Visceral Leishmaniasis Surveillance and Control Program (VLSCP) ${ }^{4}$ has as main objective the reduction of HVL morbidity and lethality rates. Control actions are directed towards early diagnosis and timely treatment of the disease, associated with vector and enzootic canine control, as dogs are the main urban reservoir of the disease 1.

The city of Belo Horizonte (Minas Gerais State) has been endemic for VL for two decades. Interventions adapted for the local reality have had a positive impact on VL control in the last decade 5,6. The use of health intervention assessment indicators is essential to gauge the effectiveness, sustainability and feasibility of the proposed actions 7,8. For example, continuous evaluations are performed in the city using VL control data obtained from the enzootic data organization and management information system (Zoonoses Control Information System - SCZOO), a routine municipal service.

In this context, this study analyzes actions developed for VL control based on epidemiological canine reservoir control indicators and the associations between these indicators and HVL occurrence in Belo Horizonte. It proposes a feasible approach to be used by the VL control services and for analyzing control strategies.

\section{Methods}

\section{Study area}

The first human cases of VL in Belo Horizonte were confirmed in 1994, and in that year investments were initiated for VL control. A total of 2,375,151 inhabitants live in the city (Brazilian Institute of Geography and Statistics - IBGE. https://cidades.ibge.gov.br/brasil/mg/belo-horizonte/panorama, accessed on Jan/2018), which is administratively divided into nine Health Districts, which are subdivided into 152 health center coverage areas. Delimitation of coverage areas corresponds to census classification and considers both physical and geographic barriers, in addition to demographics, in order to facilitate access. The local basic health service and endemic disease surveillance and control actions are organized according to the health center coverage area, which is the sanitary reference for the assessed population. The implementation of surveillance and control activities is carried out by specific staff comprising agents distributed throughout the district, according to transmission risk assessed by the city 6 .

\section{Study design}

This is an observational longitudinal study, where indicators were used to assess the control of the canine visceral leishmaniasis (CVL) reservoir, consolidated for Belo Horizonte.

\section{Variables and data sources}

Data on the CVL reservoir were obtained from the SCZOO, while data on HVL cases were obtained from the Brazilian Information System on Diseases of Notification (SINAN), both from 2006 to 2013. Human population data were obtained from the 2010 Demographic Census, available at the IBGE website (https://cidades.ibge.gov.br/brasil/mg/belo-horizonte/panorama, accessed on Jan/2018), while 
canine population data were obtained from the annual canine census conducted by the municipality (data provided by the service).

The number of reported human cases $(H V L)$, the proportion of the canine population to the human population (relhoc) and other indicators were proposed based on the surveillance and control activities in the city. The epidemiological canine reservoir control indicators variables are available at the SCZOO database, namely the proportion of dogs tested by ELISA (Enzyme Linked Immuno Sorbent Assay) and IFAT (Immunofluorescence Antibody Test) annually carried out during census serological survey (cobic), the proportion of ELISA and IFAT canine positive serological test (seroprev $A$, seroprev $B$ ), and the proportion of dogs with positive serological results by the ELISA test that were not euthanized (neutan) (Box 1). The latter indicator is justified due to the high disagreement between the diagnostic platform tests (ELISA+IFAT) and a high seroconversion observed with IFAT in dogs retested after about three months 6 in Belo Horizonte.

\section{Data analysis}

A descriptive analysis was performed for the assessed epidemiological indicators of canine control, as well as for the HVL incidence ratios throughout the study. Existing correlations were detected by Spearman's correlation, while possible associations between the proposed indicators were verified by applying a generalized linear model (GLM).

In situations where the response variable is due to other, non-normal, distributions, or in which the relationship between the response variable and the explanatory variables was not linear, the use of models equivalent to those developed for the Gaussian linear regression model, such as GLM, was used 9 .

The modeling analysis was divided into two moments. The first, (i), comprised the analysis of possible associations between the canine epidemiological indicators, where the dependent variable was set as canine seroprevalence between 2007 and 2013 (seroprev A) and the independent variables were set as canine seroprevalence (seroprev B); percentage of non-euthanized ELISA-reactive dogs (neutan); relation between the human and canine populations (relhoc); as well as testing coverage of the canine population obtained from census surveys (cobic). All variables were collected between 2006 and

\section{Box 1}

Indicators used for data modeling of the present study.

\begin{tabular}{|c|c|}
\hline INDICATORS/STUDY VARIABLES & CALCULATION \\
\hline $\begin{array}{c}\text { seroprev A - proportion of canine seroprevalence (2007 to 2013) } \\
\text { obtained from census-based sorological surveys }\end{array}$ & $\begin{array}{c}\text { Number of reactive serological tests (ELISA+IFAT) / Number of tested } \\
\text { dogs (\%) }\end{array}$ \\
\hline $\begin{array}{c}\text { seroprev B - proportion of canine seroprevalence (2006 to 2012) } \\
\text { obtained from census-based sorological surveys }\end{array}$ & $\begin{array}{c}\text { Number of reactive serological tests (ELISA+IFAT) / Number of tested } \\
\text { dogs (\%) }\end{array}$ \\
\hline $\begin{array}{c}\text { neutan - proportion of non-euthanized ELISA reactive dogs (2006 to } \\
\text { 2012) }\end{array}$ & $\begin{array}{c}\text { Total of non-euthanized ELISA-reactive dogs / Total of ELISA-reactive } \\
\text { dogs (\%) }\end{array}$ \\
\hline $\begin{array}{c}\text { relhoc - relationship between the human and canine population (2006 } \\
\text { to 2012) }\end{array}$ & $\begin{array}{c}\text { Ratio between the human and canine population } \\
\text { cobic - annual canine population coverage testing obtained from } \\
\text { serological census sorological surveys (2006 to 2012) }\end{array}$ \\
\hline years - study years (2006 to 2013) & $\begin{array}{c}\text { Total of dogs tested during census sorological surveys per year / Annual } \\
\text { canine population }\end{array}$ \\
\hline$H V L-$ human number & Years considered in the study \\
\hline Human population & Population data obtained from the 2010 Demographic Census * \\
\hline
\end{tabular}

ELISA: Enzyme Linked Immuno Sorbent Assay; IFAT: Immunofluorescence Antibody Test.

* Brazilian Institute of Geography and Statistics (https://cidades.ibge.gov.br/brasil/mg/belo-horizonte/panorama, accessed on Jan/2018). 
2012, while the study itself continued until 2013. A normal family distribution (Gaussian) was used for the response variable seroprev, which underwent a natural logarithm (Ln) type transformation. This variable was chosen because it was the most like a normal distribution. The second moment, (ii), comprised the association between the number of HVL case between 2007 and 2013 and the independent variables related to dogs (seroprev A, seroprev B, relhoc, neutan) and years. These analyses were done with a one-year interval considering the results obtained in other studies performed in the same municipality 5,10 .

A negative binomial family distribution was used to count HVL cases. The offset was the resident population of Belo Horizonte.

\section{Results}

Our results demonstrate the association between the control indicators of the canine reservoir and the number of HVL cases in the study period. The data analysis indicated an increasing trend for canine population testing coverage obtained during census serological surveys and a decreasing trend for canine seroprevalence indicators and incidence of the disease (Figure 1; Table 1).

The correlation between $H V L$ and seroprev $A(0.750)$ and seroprev $B(0.696)$ was positive at $\mathrm{p}<0.01$. This indicates that increased canine seroprevalence is associated to the increase of HVL incidence rates. On the other hand, an inverse correlation was detected between $H V L$ and years $(-0.616$; $\mathrm{p}<$ 0.01 ), indicating that HVL incidence rates decreased throughout the study period. The higher the human/dog ratio (relhoc, -0.617 ; $<<0.01$ ), the lower the disease incidence in the municipality. In addition, seroprev $A$ and seroprev $B$ displayed the same trend, where increased seroprevalence in one year (seroprev B) was associated to the increasing of seroprevalence the following year (seroprev $A$ ). The percentage of non-euthanized dogs (neutan) and annual canine population testing coverage obtained from serological census surveys (cobic) were not correlated with the dependent variables, but were left in the models in order to observe fitting in relation to the other assessed variables (Table 1). The GLM results indicate that, during the first moment (i) there was an effect of years, seroprev B, neutan and relhoc on canine seroprevalence (Table 2). This effect was reversed for years and relhoc, indicating that the more recent the year, the lower the canine seroprevalence, and that the higher the human/ dog ratio, the lower the canine seroprevalence, pointing to a decreasing situation. The seroprev $B$ and neutan indicators displayed a positive effect, where a high seroprevalence during the previous year (seroprev B) and a high proportion of non-euthanized (neutan) ELISA-seroreactive dogs were associated to a higher canine seroprevalence (Table 2).

In the second moment (ii), the final model indicated an association between $H V L$ and three of the four analyzed indicators (Table 3). The increase in one canine seroprevalence unit during the previous year (seroprev B) increased the HVL rate in 13\%, controlled by seroprev $A$ and by the relationship between the human and canine populations (relhoc) between 2006 and 2012. The increase in one canine seroprevalence unit (seroprev $A$ ) increased the HVL rate in $12 \%$, controlled by seroprev $B$ and relhoc. On the other hand, an increase in one relhoc unit led decreased the HVL rate in 13\%, controlled by both seroprev $B$ and seroprev $A$ (Table 3). 


\section{Figure 1}

Epidemiological indicators of canine reservoir control and human visceral leishmaniasis (HVL) incidence distribution from 2006 to 2013 . Belo Horizonte, Minas Gerais State, Brazil.

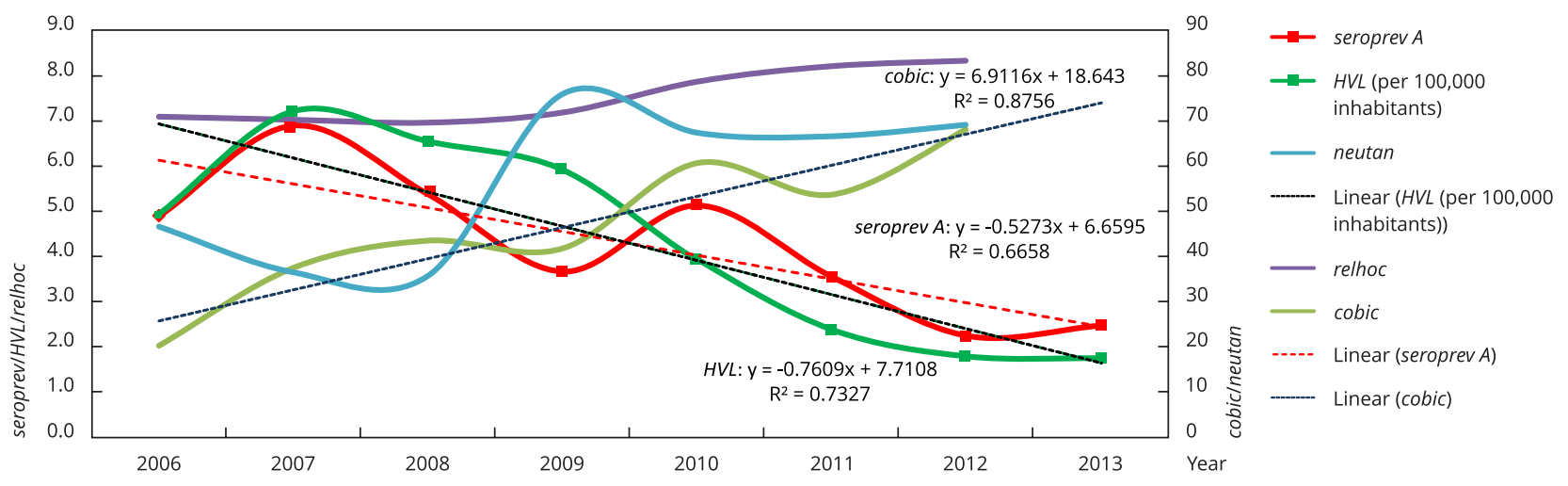

Table 1

Correlation matrix between epidemiological indicators of canine reservoir control and human visceral leishmaniasis (HVL) incidence rate using Spearman's correlation coefficient. Belo Horizonte, Minas Gerais State, Brazil.

\begin{tabular}{|c|c|c|c|c|c|c|c|}
\hline & seroprev $A$ & seroprev B & years & neutan & relhoc & $H V L$ & cobic \\
\hline seroprev $A$ & 1.000 & & & & & & \\
\hline \multicolumn{8}{|l|}{$\mathrm{p}$-valor } \\
\hline seroprev $B$ & 0.685 * & 1.000 & & & & & \\
\hline $\mathrm{p}$-valor & 0.000 & & & & & & \\
\hline years & -0.724 * & -0.599 * & 1.000 & & & & \\
\hline $\mathrm{p}$-valor & 0.000 & 0.000 & & & & & \\
\hline neutan & 0.020 & -0.175 & 0.043 & 1.000 & & & \\
\hline p-valor & 0.875 & 0.170 & 0.739 & & & & \\
\hline relhoc & -0.581 * & -0.564 * & 0.406 * & 0.175 & 1.000 & & \\
\hline p-valor & 0.000 & 0.000 & 0.001 & 0.170 & & & \\
\hline$H V L$ & 0.750 * & 0.696 * & -0.616 * & -0.151 & -0.617 * & 1.000 & \\
\hline $\mathrm{p}$-valor & 0.000 & 0.000 & 0.000 & 0.237 & 0.000 & & \\
\hline cobic & -0298 ** & -0.166 & 0.611 * & -0.019 & 0.147 & -0.141 & 1.000 \\
\hline p-valor & 0.018 & 0.194 & 0.000 & 0.883 & 0.251 & 0.271 & \\
\hline
\end{tabular}

$* p<0.01$;

$* * \mathrm{p}<0.05$ 
Table 2

Final estimates for the generalized linear model (GLM) parameter. Moment (i) - seroprev dependent variable.

\begin{tabular}{lccc}
\hline Explanatory variables & Coefficient & SE & RR (CI) \\
\hline Intercept & $293.733^{*}$ & 45.791 & - \\
years & $-0.146^{*}$ & 0.022 & $0.864(0.828-0.902)$ \\
seroprev B & $0.146^{*}$ & 0.025 & $1.157(1.102-1.215)$ \\
neutan & $0.015^{*}$ & 0.003 & $1.015(1.009-1.021)$ \\
relhoc & $-0.077 * *$ & 0.032 & $0.926(0.869-0.985)$ \\
AIC & 14.61 & & \\
\hline
\end{tabular}

AIC: Akaike information criterion; Cl: confidence interval; RR: rate ratio; SE: standard error.

* $\mathrm{p}<0.001$;

** $p<0.05$

\section{Table 3}

Final estimates for the generalized linear model (GLM) parameter. Moment (ii) - human visceral leishmaniasis (HVL) cases counts dependent variable.

\begin{tabular}{lccc}
\hline Explanatory variables & Coefficient & SE & RR (CI) \\
\hline Intercept & $-10.060 *$ & 0.505 & - \\
seroprev $B$ & $0.122 * *$ & 0.038 & $1.1297(1.048-1.217)$ \\
seroprev $A$ & $0.114 * *$ & 0.039 & $1.1207(1.038-1.209)$ \\
relhoc & $-0.141 * *$ & 0.053 & $0.868(0.782-0.963)$ \\
AlC & 363.5 & & \\
\hline
\end{tabular}

AIC: Akaike information criterion; Cl: confidence interval; RR: rate ratio; SE: standard error.

$* p<0.001$

$* * p<0.01$

\section{Discussion}

The results obtained suggest that canine seroprevalence, human/dog ratios and non-euthanized ELISA-reactive dogs left in the environment are adequate predictors for canine enzootic transmission and occurrence of HVL in the city of Belo Horizonte.

A higher seroprevalence in the previous year was associated to a positive effect on the dependent canine seroprevalence variable, as reported in other studies 11,12,13,14. Despite existing questions concerning the accuracy of serological VL diagnosis (ELISA and IFAT) in dogs 15,16, other studies also have identified correlation between human and canine cases of VL in Belo Horizonte, in different periods 10,17. These findings agree with those obtained in the present study and make it possible to infer that the control of the main urban reservoir 18 of this disease is an important tool of the surveillance and control. Herein, the association of the neutan indicator with the higher canine seroprevalence may be related to the maintenance of infected dogs in the environment for longer periods of time, due to the increased disagreement observed between the applied serological tests (ELISA+IFAT) 6 , until the change of the diagnostic platform (DPP+ELISA) 19 in Belo Horizonte that occurred in 2013. This fact may had allowed the maintenance of dogs in the environment for a longer period without any form of preventive protection against the vector bites 20,21,22,23. These findings reinforce the need for control on the canine reservoir, reducing the chance of becoming a source of infection for the vector. An option to control the disease in dogs is the use of the collars with repellent products that, in addition to reducing the canine seroprevalence, reduce the abundance and level of infection in the vectors $4,20,21$. 
The results demonstrate that, the more recent the assessed year and the smaller the dog population in the municipality, the lower the canine seroprevalence. The increase or the maintenance of canine population testing coverage obtained by census surveys was not a significant variable by the final model. However, this may have influenced the results obtained due the maintenance of continuous surveillance on the main urban reservoir of VL. The size of the canine population was proven an adequate predictor for control of the disease. The IBGE survey has indicated a great presence of these animals in domestic environments 23.

In this regard, it is important to implement initiatives to ensure their effective management, focusing on responsible custody, animal sanitary and reproductive control 18. Another important aspect noted herein was the impact of control action on the enzootic canine reservoir. Besides the maintenance, the territorial expansion and implementation of control actions in both time and space by the municipal program resulted in a reduced number of euthanized dogs due to the decreased canine seroprevalence 5,6. The second analysis investigated the effect of canine reservoir control indicators on HVL rates. Increased canine seroprevalence both in the previous and current analyzed year were directly associated with the rate of infection. In addition, increased human/dog ratios, led to a decreased number of cases. These results meet the main VLSCP objective, which aims to reduce VL morbidity and mortality rates 4 , and were important for Belo Horizonte, which also presented a decrease in the number of deaths by the disease during the study period 24 .

This study infers that, despite the difficulties on implementation of VLSCP 25 , workable and sustainable proposals 26 are essential in order to continue the search for control of the disease, for both humans and animals 4,27. The growth of animal populations requires integrated actions increasingly focused on one health, with respect for animals and the precepts of public health, responsible ownership and management of animal populations 28 . Societal participation is indispensable; partnerships with educational, research institutions and with the public governance are advised, in order to get adequation of any control action and for continuous implementation of the proposed measures 28,29.

Regarding the type of epidemiological study, this proposal is directly related to the importance of evaluating secondary data from VL control program implementation 5,8. However, this methodology can corroborate to the discussion that covers the entire process of structuring policies for obtaining, processing and analyzing data concerning endemic control program implementation, in order to monitor proposed activities and to enable studies required for improvement 8 . The continuation of this type of proposed surveillance and control program is complex and costly and the proposed control strategies should be carried out in an integrated manner 4,27. Vector control, the most indicated action for the control of vector-borne diseases, is difficult to implement 27 and has been reported as the least adequate among other measures employed in Belo Horizonte 6. Reservoir control, the most feasible in operational terms, has been questioned, due to technical and ethical issues 27,29 . The implementation of the surveillance and control program is inconsistent, even in municipalities experiencing major problems resulting from HVL incidence and lethality 25. However, Belo Horizonte invested in disease control with positive results, which require continuity to avoid reversion of the situation 5,6,26. Finally, one of the limitations of this study is with its reproducibility, mainly regarding the information on seropositive animals and canine census survey testing coverage in urban areas reporting the disease, in contrast to Belo Horizonte, where the secondary reservoir quality data used here are available.

\section{Conclusion}

The monitoring and evaluation of the effectiveness of surveillance and control actions carried out in public health programs are fundamental as they allow the review of strategies in view of the obtained results and the new possibilities of control strategies. This study provides indicators that can be used for these purposes in different places, and different contexts of VL surveillance, as ways of monitoring the VLSCP. Nevertheless, we emphasize that the use of new strategies of control of the disease and the participation of the population are fundamental for an effective and efficient disease control. 


\section{Contributors}

All authors contributed in all stages of production of the article.

\section{Additional informations}

ORCID: Maria Helena Franco Morais (0000-00026025-2774); Paulo Chagastelles Sabroza (00000001-8235-0562); José Eduardo Pessanha (in memorian); Andrea Sobral (0000-0003-0552-771X).

\section{References}

1. World Health Organization. Global Health Observatory (GHO) data. https://www.who. int/gho/neglected_diseases/leishmaniasis/en/ (accessed on Jan/2018).

2. Bezerra JMT, de Araújo VEM, Barbosa DS, Martins-Melo FR, Werneck GL, Carneiro M. Burden of leishmaniasis in Brazil and federated units, 1990-2016: findings from Global Burden of Disease Study 2016. PLoS Negl Trop Dis 2018; 12:e006697.

3. Pan American Health Organization. Leishmaniasis: epidemiological report of the Americas. http://iris.paho.org/xmlui/bitstream/ handle/123456789/34856/LeishReport6_eng. pdf? sequence $=1 \&$ isAllowed $=y$ (accessed on Sep/2018).

4. Departamento de Vigilância Epidemiológica, Secretaria de Vigilância em Saúde, Ministério da Saúde. Manual de vigilância e controle da leishmaniose visceral. Brasília: Editora do $\mathrm{Mi}-$ nistério da Saúde; 2006.

5. Bruhn FRP, Morais MHF, Cardoso DL, Bruhn NCP, Ferreira F, Rocha CMBMD. Spatial and temporal relationships between human and canine visceral leishmaniases in Belo Horizonte, Minas Gerais, 2006-2013. Parasit Vectors 2018; 11:372.

6. Morais MHF, Fiuza VOP, de Araújo VEM, de Menezes FC, Carneiro M. Avaliação das atividades de controle da leishmaniose visceral em Belo Horizonte, Minas Gerais, 2006-2011. Epidemiol Serv Saúde 2015; 24:485-96.

7. Organização Pan-Americana da Saúde. Programa Regional de Leishmanioses: Américas 2010-2017. https://www.paho.org/hq/dmdo cuments/2017/2017-cha-prog-reg-leish-ame ricas-pt.pdf (accessed on Mar/2018).

8. Santos EM, Cruz MM, editors. Avaliação em saúde: dos modelos teóricos à prática da avaliação de programas de controle de processos endêmicos. Rio de Janeiro: Editora Fiocruz; 2014.

9. Nelder JA, Wedderburn RWM. Generalized linear models. J R Stat Soc Ser A 1972; 135:370-84.

10. Oliveira CL, Assunção RM, Reis IA, Proietti FA. Spatial distribution of human and canine visceral leishmaniasis in Belo Horizonte, Minas Gerais State, Brasil, 1994-1997. Cad Saúde Pública 2001; 17:1231-9.

11. Coura-Vital W, Marques MJ, Veloso VM, Roatt BM, Aguiar-Soares RDO, Reis LES, et al. Prevalence and factors associated with Leishmania infantum infection of dogs from an urban area of Brazil as identified by molecular methods. PLoS Negl Trop Dis 2011; 5:e1291.

12. Julião FS, Souza BMPS, Freitas DS, Oliveira LS, Larangeira DF, Dias-Lima AG, et al. Investigação de áreas de risco como metodologia complementar ao controle da leishmaniose visceral canina. Pesq Vet Bras 2007; 27:319-24. 
13. Barboza DCPM, Gomes-Neto CMB, Leal DC, Bittencourt DVV, Carneiro AJB, Souza BMPS, et al. Estudo de coorte em áreas de risco para leishmaniose visceral canina, em municípios da Região Metropolitana de Salvador, Bahia, Brasil. Revista Brasileira de Saúde e Produção Animal 2006; 7:152-63.

14. Amóra SSA, Santos MJP, Alves ND, Costa SCG, Calabrese KS, Monteiro AJ, et al. Fatores relacionados com a positividade de cães para leishmaniose visceral em área endêmica do Estado do Rio Grande do Norte, Brasil. Ciênc Rural 2006; 36:1854-9.

15. Regina-Silva S, Fortes-Dias CL, Michalsky EM, França-Silva JC, Quaresma PF, da Rocha Lima AC, et al. Evaluation of parasitological examination, kDNA polymerase chain reaction and rK39-based immunochromatography for the diagnosis of visceral leishmaniasis in seropositive dogs from the screening-culling program in Brazil. Rev Soc Bras Med Trop 2014; 47:462-8

16. Laranjeira DF, Matta VLR, Tomokane TY, Marcondes M, Corbet CEP, Laurenti MD, et al. Serological and infection statuses of dogs from a visceral leishmaniasis-endemic area. Rev Saúde Pública 2014; 48:563-71.

17. Araújo VEM, Pinheiro LC, Almeida MCM, Menezes FC, Morais MHF, Reis IA, et al. Relative risk of visceral leishmaniasis in Brazil: a spatial analysis in urban area. PLoS Negl Trop Dis 2013; $7: \mathrm{e} 2540$.

18. Belo VS, Struchiner CJ, Werneck GL, Barbosa DS, de Oliveira RB, Teixeira Neto RG, et al. A systematic review and meta-analysis of the factors associated with Leishmania infantum infection in dogs in Brazil. Vet Parasitol 2013; 195:1-13.

19. Coordenação Geral de Doenças Transmissíveis; Coordenação Geral de Laboratórios de Saúde Pública, Secretaria de Vigilância em Saúde, Ministério da Saúde. Nota Técnica Conjunta no 1/2011. Esclarecimentos sobre substituição do protocolo diagnóstico da leishmaniose visceral canina (LVC). Brasília: Ministério da Saúde; 2011.

20. Kazimoto TA, Amora SSA, Figueiredo FB, Magalhães JME, Freitas YBN, Sousa MLR, et al. Impact of $4 \%$ deltamethrin-impregnated dog collars on the prevalence and incidence of canine visceral leishmaniasis. Vector Borne Zoonotic Dis 2018; 18:356-63.
21. Leite BMM, Solcà MS, Santos LCS, Coelho LB, Amorim LDAF, Donato LE, et al. The mass use of deltamethrin collars to control and prevent canine visceral leishmaniasis: a field effectiveness study in a highly endemic area. PLoS Negl Trop Dis 2018; 12:e0006496.

22. Silva RA, Andrade AJ, Quint BB, Raffoul GES, Werneck GL, Ragnel EF, et al. Effectiveness of dog collars impregnated with $4 \%$ deltamethrin in controlling visceral leishmaniasis in Lutzomyia longipalpis (Diptera: Psychodidade: Phlebotominae) populations. Mem Inst Oswaldo Cruz 2018; 113:e170377.

23. Instituto Brasileiro de Geografia e Estatística. Pesquisa Nacional de Saúde 2013: acesso e utilização dos serviços de saúde, acidentes e violências. Brasil, grandes regiões e unidades da federação. Rio de Janeiro: Instituto Brasileiro de Geografia e Estatística; 2015.

24. Prefeitura de Belo Horizonte. Informações sobre leishmaniose visceral. https://prefeitura. pbh.gov.br/ (accessed on 15/Jan/2017).

25. von Zuben APB, Donalísio MR. Dificuldades na execução das diretrizes do Programa de Vigilância e Controle da Leishmaniose Visceral em grandes municípios brasileiros. Cad Saúde Pública 2016; 32:e00087415.

26. de Arruda RMF, Cardoso DT, Teixeira-Neto RG, Barbosa DS, Ferraz RK, Morais MHF, et al. Space-time analysis of the incidence of human visceral leishmaniasis (VL) and prevalence of canine VL in a municipality of southeastern Brazil: identification of priority areas for surveillance and control. Acta Trop 2019; 197:105052.

27. Werneck GL. Visceral leishmaniasis in Brazil: rationale and concerns related to reservoir control. Rev Saúde Pública 2014; 48:851-6.

28. International Companion Animal Management Coalition. Humane dog population management guidance. https://oldrpawe.oie.int/ (accessed on 17/Mar/2017).

29. Alves EB, Figueiredo FB, Rocha MF, Werneck GL. Dificuldades operacionais no uso de coleiras caninas impregnadas com inseticida para o controle da leishmaniose visceral, Montes Claros, MG, 2012. Epidemiol Serv Saúde 2018; 27:e217469. 


\section{Resumo}

O estudo aplica indicadores referentes ao controle do reservatório canino da leishmaniose visceral na cidade de Belo Horizonte, Minas Gerais, Brasil. Os dados foram obtidos do Sistema de Controle de Zoonoses (SCZOO) e do Sistema de Informação de Agravos de Notificação (SINAN). Começamos com a análise das associações existentes entre indicadores epidemiológicos caninos, onde a variável dependente foi a soroprevalência canina-A (de 2007 a 2013) e a variável independente foi a soroprevalência canina-B (de 2006 a 2012); o percentual de cães positivos de acordo com o teste ELISA e que não foram sacrificados; a relação entre as populações humana e canina; a cobertura da testagem da população canina de acordo com inquéritos censitários e os anos de estudo (de 2006 a 2013). Em seguida, examinamos a associação entre casos de leishmaniose visceral humana (LVH) entre 2007 e 2013 e as variáveis citadas relacionadas aos cães e aos anos. A análise estatística usou um modelo linear generalizado (MLG). Os aumentos de uma unidade na soroprevalência canina-B e soroprevalência canina-A estiveram associados a aumentos de $13 \%$ e $12 \%$ nas taxas de LVH, respectivamente. Um aumento de uma unidade na razão humano/ cão esteve associado a uma diminuição de 13\% nas taxas de LVH. A soroprevalência canina, a relação humano/cão e a não-eutanásia de cães ELISA-reativos foram indicadores adequados para analisar a transmissão enzoótica canina e a ocorrência de casos de LVH.

Leishmaniose Visceral; Indicadores de Serviços; Vigilância Epidemiológica

\section{Resumen}

El estudio aplica indicadores referentes al control del reservorio canino de la leishmaniosis visceral en la ciudad de Belo Horizonte, Minas Gerais, Brasil. Los datos fueron obtenidos del Sistema de Control de Zoonosis (SCZOO) y del Sistema Brasileño de Información de Enfermedades de Notificación (SINAN). Comenzamos con el análisis de las asociaciones existentes entre indicadores epidemiológicos caninos, donde la variable dependiente fue la seroprevalencia canina-A (de 2007 a 2013) $y$ la variable independiente fue la seroprevalencia canina-B (de 2006 a 2012); el porcentaje de perros positivos, de acuerdo con el test ELISA, y que no fueron sacrificados; la relación entre las poblaciones humana y canina; la cobertura del test de la población canina, de acuerdo con encuestas censales y los años de estudio (de 2006 a 2013). En seguida, examinamos la asociación entre casos de leishmaniosis visceral humana (LVH) entre 2007 y 2013 y las variables citadas, relacionadas con los perros y los años. El análisis estadístico usó un modelo lineal generalizado (MLG). Los aumentos de una unidad en la seroprevalencia canina-B $y$ seroprevalencia canina-A estuvieron asociados a aumentos de $13 \%$ y $12 \%$ en las tasas de LVH, respectivamente. Un aumento de una unidad en la razón humano/perro estuvo asociado a una disminución de un $13 \%$ en las tasas de LVH. La seroprevalencia canina, la relación humano/perro y la no-eutanasia de perros ELISA-reactivos fueron indicadores adecuados para analizar la transmisión enzoótica canina y la ocurrencia de casos de LVH.

Leishmaniasis Visceral; Indicadores de Servicios; Vigilancia Epidemiológica
Submitted on 26/Mar/2019

Final version resubmitted on 20/Oct/2019 Approved on 19/Nov/2019 